Krzysztof BIERNAT

IEiB UKSW Warszawa

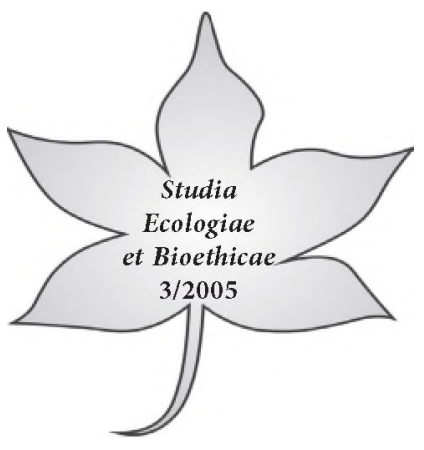

\title{
Prognoza rozwoju paliw płynnych
}

\section{Wprowadzenie, podstawowe definicje i pojęcia}

Zmiany konstrukcji silników spalinowych i urządzeń grzewczych powodowane głównie chęcią zwiększenia ich sprawności przy jednoczesnej poprawie ekonomiki eksploatacji, a także zaostrzające się wymagania z zakresu ochrony środowiska wymuszają również zmiany w asortymencie i jakości paliw do tych urządzeń. Paliwa, stanowiące źródła zasilania wszelkiego typu urządzeń powinny być traktowane jako istotny element konstrukcyjny, uwzględniany w fazie projektowania, i eksploatacyjny układu urządzenie-paliwo. Ze względu na swoje funkcje w takim układzie paliwo nie może być prawidłowo definiowane bez podania jego przeznaczenia, dopuszczalnego zakresu właściwości i sposobu ich oznaczania.

A zatem wszelkie substancje, które w efekcie procesów utleniania z wysokim efektem energetycznym mogą stanowić źródło energii, należy definiować jako materiały lub poprawniej substancje palne.

Substancje palne, w stosunku do których możliwe jest technicznie przeprowadzenie procesu spalania w sposób kontrolowany oraz istnieją przesłanki umożliwiające wykorzystanie uzyskanej energii z tego procesu powinny być określane jako substancje (materiały) paliwowe. Kompozycja substancji paliwowych, o określonych właściwościach i metodach ich oznaczania, o przewidywanym zakresie zastosowań może być już uznawana jako paliwo niestandardowe. Z kolei paliwo niestandardowe może stać się paliwem standardowym czyli normatywnym, jeżeli na to paliwo zostanie ustanowiona norma przedmiotowa, zaakceptowana przez producentów silników lub urządzeń grzewczych, z jednoznacznym określeniem:

- zakresu (stosowania) normy;

- norm powołanych;

- sposobu pobierania próbek;

- oznakowania systemu dystrybucyjnego;

- ogólnych i szczegółowych wymagań oraz metod ich oznaczania;

- niezbędnych, dodatkowych danych dotyczących np.: specyficznych metod oznaczania niektórych wymagań, magazynowania, bezpieczeństwa bhp i ppoż. itp. 
W wielu źródłach paliwa niestandardowe określane są wysoce niepoprawnym terminem: „paliwa alternatywne”. Pomijając fakt, że alternatywa może być tylko jedna to dla silnika spalinowego lub urządzenia grzewczego nie ma żadnego znaczenia jakie były źródła komponentów paliwowych i jakimi metodami je uzyskiwano. Z punktu widzenia teorii eksploatacji ważne jest jedynie aby paliwo spełniało odpowiednie wymagania danego rodzaju tych urządzeń. Innymi słowy paliwo dla każdego z tych urządzeń, w uproszczeniu może być paliwem dobrym lub złym.

Nie wnikając w rozważania z zakresu termodynamiki można przyjąć, że w procesie spalania paliw następuje zamiana energii wewnętrznej paliwa na sumę ciepła i pracy. Jeżeli praca ta będzie pracą objętościową to energia wewnętrzna paliwa może być przetworzona $z$ większą lub mniejszą sprawnością na ciepło pomniejszone o wartość pracy objętościowej. Należy pamiętać, że energia nie może być wytwarzana w żadnym z procesów, a jedynie przetwarzana lub wydzielana i możliwa do wykorzystania w procesie kolejnej przemiany termodynamicznej. Stąd też przyjmując obiegowe i wysoce niepoprawne określanie niektórych form energii jako „energia odnawialna” można jednoznacznie stwierdzić, że wszystkie silniki i urządzenia grzewcze są zasilane energią odnawialną, ponieważ jeżeli zapas energii wewnętrznej zawarty w paliwie zostanie wyczerpany poprzez całkowite spalenie paliwa, to na każdej stacji paliw, hurtowni lub składzie można tą energię odnowić, wprowadzając do zbiorników paliwowych danego urządzenia zakupione paliwo.

W perspektywie najbliższych 50-200 lat, zapasy ropy naftowej jako surowca do produkcji dotychczas stosowanych ciekłych paliw standardowych należy uznać za wystarczające. Do tej pory trudno oszacować zapasy innych paliwowych surowców kopalnych, z których możliwe jest technologicznie wytwarzanie paliw ciekłych. Technologie wytwarzania silników spalinowych i urządzeń grzewczych oraz paliw ciekłych są już tak głęboko zaawansowane, że energia zmagazynowana w tych paliwach pochodzących z przeróbki gazu ziemnego, ropy naftowej i węgla wystarczać może na bliżej nieokreślony okres, nie mniejszy niż 100 i więcej lat.

Koronnym argumentem przeciwników eksploatacji wysokojakościowych paliw węglowodorowych jest nadmierne zanieczyszczanie środowiska produktami spalania tych paliw grożące efektem cieplarnianym (ditlenek węgla), zwiększaniem „dziury ozonowej", nadmierną emisją tlenków azotu i szkodliwą emisją produktów spalania związków siarki. Wymagania jakościowe na paliwa ograniczają znacznie, nawet do granicy wykrywalności metody oznaczania zawartość siarki, a procesy spalania w powietrzu innych substancji palnych, czy też paliw niestandardowych wnosić także muszą do atmosfery analogiczne ilości gazowych produktów spalania, zależne o składu elementarnego i stechiometrii reakcji spalania.

Współczesne paliwa o ostrych wymaganiach jakościowych oznaczanych coraz bardziej wyrafinowanymi metodami badań są znacznie bardziej zgodne 
z działających na nie wymuszeniami. Ze względu na radykalne zmiany w konstrukcjach silników spalinowych o zapłonie iskrowym i samoczynnym, a także urządzeń grzewczych i wzrostem wymuszeń w stosunku do stosowanych w nich płynach eksploatacyjnych wzrastają wymagania jakościowe na paliwa. Wymagania te dość istotnie związane są nie tylko z budową układów zasilania i spalania tych urządzeń, ale także z zaostrzającymi się wymaganiami z zakresu ochrony środowiska.

Paliwa do silników spalinowych i urządzeń grzewczych muszą zatem spełniać następujące wymagania, związane bezpośrednio lub pośrednio z zapewnieniem odpowiedniej sprawności, zużycia paliwa i ochroną środowiska oraz ogólnie racjonalności eksploatacji:

- wymagania zapewniające właściwy transport wewnętrzny paliwa (wymagania układu zasilania);

- wymagania zapewniające prawidłowe rozpylenie i odparowanie paliwa;

- wymagania zapewniające właściwe spalanie paliwa;

- wymagania związane z oddziaływaniem paliw i produktów ich spalania na środowisko;

- wymagania związane z magazynowaniem, transportem i dystrybucją paliw;

- wymagania związane ze sposobami postępowania z paliwami nie spełniającymi określonych norm przedmiotowych.

\section{Kierunki modyfikacji i rozwoju źródeł napędu w pojazdach kołowych}

Modyfikacja i rozwój współczesnych źródeł napędu podyktowany jest głównie ekonomizacją ich eksploatacji poprzez zmniejszenie zużycia paliwa i jednoczesnym podwyższaniem sprawności oraz minimalizacji negatywnych oddziaływań procesu eksploatacji na środowisko. Ze względu na zmniejszające się zasoby surowców i paliw kopalnych prowadzone są także prace badawcze zmierzające do powstawania innych niż dotychczas stosowane źródła napędu zasilanych niewęglowodorowymi nośnikami energii.

Z powyższych względów w projektowaniu i konstruowaniu pojazdów i ich źródeł napędu uwzględnia się przede wszystkim:

- zwiększenie sprawności silników spalinowych poprzez między innymi stosowanie innych niż dotychczas źródeł napędu o wysokiej sprawności;

- zmniejszanie masy pojazdów;

- zmniejszanic oporów aerodynamicznych;

- zmniejszaniem oporów toczenia.

$\mathrm{Z}$ tego powodu poszukiwane są nowe rozwiązania w konstrukcji źródeł napędu jak i coraz bardziej doskonałe paliwa, których zastosowanie pozwoli, [1] zgodnie z hasłem wywołanym w USA, przebycie 80 mil $(128,75 \mathrm{~km})$, samocho- 
dem zasilanym 1 galonem paliwa (3,787 l) co daje w przeliczeniu $31 / 100 \mathrm{~km}$. Osiągnięcie tego celu może być wynikiem takich działań jak:

- efektywniejsze przetwarzanie energii w silnikach pozwalające między innymi zwiększenie sprawności cieplnej silników o zapłonie samoczynnym do 44\%;

- zmniejszenie zapotrzebowania energii w procesie przemieszczania się pojazdu poprzez redukcje masy samochodu o 30\%, zmniejszenie oporów aerodynamicznych oraz oporów toczenia;

- wprowadzanie systemów odzysku energii do 50\%, głównie z procesów hamowania, co jest możliwe w hybrydowych źródłach napędu.

Możliwe do realizacji i częściowo już realizowane działania mające na celu zmniejszenie zużycia paliwa i obniżenie szkodliwego oddziaływania spalin przedstawiono dla silników o zapłonie iskrowym w tablicy 1, dla silników o zapłonie samoczynnym, małej mocy w tablicy 2, a w tablicy 3 dla dużych silników o zapłonie samoczynnym tak zwanej wytężonej mocy [2].

Tablica 1. Zestawienie działań obniżających toksyczność spalin i zużycie paliw w silnikach o zapłonie iskrowym

\begin{tabular}{|c|c|c|}
\hline Lp & Dzialanie & Skutki \\
\hline 1. & Zwiększanie stopnia sprężania & $\begin{array}{l}\text { Zwiększenie sprawności, obniżenie jednostkowego } \\
\text { zużycia paliwa }\end{array}$ \\
\hline 2. & Zwiększanie stopnia zawirowania & $\begin{array}{l}\text { Skrócenie czasu spalania, obniżenie emisji węglo- } \\
\text { wodorów i tlenku węgla }\end{array}$ \\
\hline 3. & Zwiększenie energii zapłonu & Możliwość spalania mieszanek ubogich \\
\hline 4. & Doładowanie dynamiczne & $\begin{array}{l}\text { Wzrost stopnia napełnienia oraz zmniejszenie } \\
\text { zużycia paliwa }\end{array}$ \\
\hline 5. & $\begin{array}{l}\text { Elektronizacja układów zasilania } \\
\text { (MPI, DMI, GDT) }\end{array}$ & $\begin{array}{l}\text { Optymalizacja składu mieszanki, regulacja jako- } \\
\text { ściowa, spalanie mieszanek ubogich (uwarstwienie } \\
\text { ładunku) }\end{array}$ \\
\hline 6. & $\begin{array}{l}\text { Wprowadzanie głowic wielozaworo- } \\
\text { wych }\end{array}$ & $\begin{array}{l}\text { Poprawa stopnia napełnienia, zmniejszenie zużycia } \\
\text { paliwa }\end{array}$ \\
\hline 7. & $\begin{array}{l}\text { Elektroniczna regulacja faz rozrządu } \\
\text { i wzniosu zaworów }\end{array}$ & $\begin{array}{l}\text { Poprawa stopnia napełnienia, zubożenie mieszanki } \\
\text { dla układów z regulacją jakościową }\end{array}$ \\
\hline 8. & Wprowadzanie recyrkulacji spalin & Obniżenie emisji tlenków azotu \\
\hline 9. & Doładowanie & $\begin{array}{l}\text { Poprawa stopnia napełnienia, zubożenie mieszanki } \\
\text { dla układów z regulacją jakościową }\end{array}$ \\
\hline 10. & $\begin{array}{l}\text { Instalowanie katalizatorów procesu } \\
\text { utleniania }\end{array}$ & Obniżenie emisji węglowodorów i tlenku węgla \\
\hline 11. & $\begin{array}{l}\text { Instalowanie katalizatorów potrójne- } \\
\text { go działania }\end{array}$ & $\begin{array}{l}\text { Obniżenie emisji tlenków azotu, węglowodorów } \\
\text { i tlenku węgla }\end{array}$ \\
\hline 12. & $\begin{array}{l}\text { Instalowanie urządzeń skracających } \\
\text { czas nagrzewania katalizatorów }\end{array}$ & $\begin{array}{l}\text { Obniżanie emisji toksycznych składników spalin } \\
\text { w procesie nagrzewania silnika, zmniejszenie } \\
\text { zużycia paliwa }\end{array}$ \\
\hline 13. & $\begin{array}{l}\text { Instalowanie urządzeń skracających } \\
\text { czas nagrzewania silnika }\end{array}$ & $\begin{array}{l}\text { Obniżanie emisji toksycznych składników spalin } \\
\text { w procesie nagrzewania silnika, zmniejszenie } \\
\text { zużycia paliwa }\end{array}$ \\
\hline
\end{tabular}




\begin{tabular}{|c|l|l|}
\hline 14. & $\begin{array}{l}\text { Instalowanie katalizatorów o małej } \\
\text { pojemności cieplnej w układzie „by- } \\
\text {-pass” }\end{array}$ & $\begin{array}{l}\text { Obniżanie emisji toksycznych składników spalin } \\
\text { w procesie nagrzewania silnika, zmniejszenie } \\
\text { zużycia paliwa }\end{array}$ \\
\hline 15. & $\begin{array}{l}\text { Zwiększanie współczynnika nadmia- } \\
\text { ru powietrza }\end{array}$ & $\begin{array}{l}\text { Obniżenie emisji tlenków azotu, zmniejszenie } \\
\text { zużycia paliwa }\end{array}$ \\
\hline 16. & $\begin{array}{l}\text { Ograniczanie zużycia olejów smaro- } \\
\text { wych }\end{array}$ & $\begin{array}{l}\text { Obniżenie emisji węglowodorów, w tym wielo- } \\
\text { pierścieniowych }\end{array}$ \\
\hline 17. & $\begin{array}{l}\text { Stosowanie paliw o obniżonej zawar- } \\
\text { tości siarki }\end{array}$ & $\begin{array}{l}\text { Obniżanie emisji związów siarki oraz większa } \\
\text { trwałość katalizatorów }\end{array}$ \\
\hline 18. & Podgrzewanie mieszanki & $\begin{array}{l}\text { Obniżanie emisji toksycznych składników spalin } \\
\text { w procesie nagrzewania silnika, zmniejszenie } \\
\text { zużycia paliwa }\end{array}$ \\
\hline
\end{tabular}

Tablica 2. Zestawienie działań obniżających toksyczność spalin i zużycie paliwa w silnikach o zapłonie samoczynnym, małej i średniej mocy

\begin{tabular}{|l|l|l|}
\hline Lp & \multicolumn{1}{|c|}{ Działanie } & \multicolumn{1}{|c|}{ Skutki } \\
\hline 1. & Zwiększanie stopnia zawirowania & $\begin{array}{l}\text { Skrócenie czasu spalania, opóźnienie samozapło- } \\
\text { nu, zmniejszenie emisji cząstek stałych, węglowo- } \\
\text { dorów i tlenku węgla }\end{array}$ \\
\hline 2. & $\begin{array}{l}\text { Optymalizacja kształtu strumienia } \\
\text { i umieszczenie wtryskiwaczy w ko- } \\
\text { morze spalania }\end{array}$ & $\begin{array}{l}\text { Skrócenie czasu spalania, opóźnienie samozapło- } \\
\text { nu, zmniejszenie emisji cząstek stałych }\end{array}$ \\
\hline 3. & Zwiększanie ciśnienia wtrysku & $\begin{array}{l}\text { Skrócenie czasu trwania etapu zwłoki samozapło- } \\
\text { nu, zmniejszenie emisji cząstek stałych }\end{array}$ \\
\hline 4. & $\begin{array}{l}\text { Elektronizacja procesu wtrysku } \\
\text { paliwa }\end{array}$ & $\begin{array}{l}\text { Optymalizacja kąta wyprzedzenia wtrysku po- } \\
\text { przez uzależnienie wartości tego kąta od większej } \\
\text { liczby parametrów }\end{array}$ \\
\hline 5. & Opóźnienie wtrysku paliwa & Obniżenie emisji tlenków azotu \\
\hline 6. & Wtrysk paliwa z dawką pilotującą & $\begin{array}{l}\text { Skrócenie okresu zwłoki samzapłonu, zmniejsze- } \\
\text { nie emisji cząstek stałych, zmniejszanie gradientu } \\
\text { ciśnienia powodujące zmniejszenie hałaśliwósci } \\
\text { silnika }\end{array}$ \\
\hline 7. & Doładowanie & $\begin{array}{l}\text { Obniżenie emisji toksycznych składników spalin, } \\
\text { wzrost sprawności }\end{array}$ \\
\hline 8. & Chłodzenie doładowanego powietrza & $\begin{array}{l}\text { Podwyższenie efektów wynikających z doładowa- } \\
\text { nia }\end{array}$ \\
\hline 9. & Wprowadzanie recyrkulacji spalin & Obniżenie emisji tlenków azotu \\
\hline 10. & $\begin{array}{l}\text { Instalowanie głowic wielozaworo- } \\
\text { wych }\end{array}$ & $\begin{array}{l}\text { Zwiększenie stopnia napełnienia, zmniejszenie } \\
\text { zużycia paliwa }\end{array}$ \\
\hline 11. & $\begin{array}{l}\text { Wprowadzenie elektronicznej regula- } \\
\text { cji faz rozrządu i wzniosu zaworów }\end{array}$ & $\begin{array}{l}\text { Ooprawa stopnia napełnienia, zmniejszanie emisji } \\
\text { tlenków azotu poprzez sterowanie procesem } \\
\text { zamykania zaworu wylotowego }\end{array}$ \\
\hline 12. & $\begin{array}{l}\text { Ograniczenie zużycia olejów smaro- } \\
\text { wych }\end{array}$ & $\begin{array}{l}\text { Obniżenie emisji cząstek stałych i węglowodorów, } \\
\text { w tym wielopierścieniowych }\end{array}$ \\
\hline 13. & $\begin{array}{l}\text { Wprowadzanie katalizatorów utlenia- } \\
\text { jących }\end{array}$ & $\begin{array}{l}\text { Obniżenie emisji cząstek stałych, węglowodorów } \\
\text { i tlenku węgla }\end{array}$ \\
\hline
\end{tabular}


Krzysztof Biernat

\begin{tabular}{|c|l|l|}
\hline 14. & Instalowanie filtrów sadzy & $\begin{array}{l}\text { Obniżenie emisji tlenku węgla oraz wpływ na } \\
\text { obniżenie emisji węglowodorów }\end{array}$ \\
\hline 15. & $\begin{array}{l}\text { Instalowanie urządzeń skracających } \\
\text { czas nagrzewania silnika }\end{array}$ & $\begin{array}{l}\text { Obniżanie emisji toksycznych składników spalin } \\
\text { w procesie uruchamiania silnika }\end{array}$ \\
\hline 16. & $\begin{array}{l}\text { Zasilanie paliwami o zmniejszonej } \\
\text { zawartości siarki }\end{array}$ & $\begin{array}{l}\text { Obniżenie emisji związków siarki i cząstek stałych, } \\
\text { wydłużenie czasu efektywnego działania kataliza- } \\
\text { torów }\end{array}$ \\
\hline
\end{tabular}

Tablica 3. Zestawienie działań obniżających toksyczność spalin i zużycie paliwa w silnikach o zapłonie samoczynnym, dużej mocy

\begin{tabular}{|c|c|c|}
\hline Lp & Dzialanie & Skutki \\
\hline 1. & $\begin{array}{l}\text { Optymalizacja kształtu poprzez spo- } \\
\text { sób umieszczenia wtryskiwaczy }\end{array}$ & $\begin{array}{l}\text { Skrócenie czasu opóźnienia wtrysku, zmniej- } \\
\text { szenie emisji cząstek stałych wraz z możliwością } \\
\text { opóźnienia wtrysku zmniejszającą emisję tlenków } \\
\text { azotu }\end{array}$ \\
\hline 2. & $\begin{array}{l}\text { Zwiększenie ciśnienia wtrysku paliwa } \\
\text { przy mniejszej intensywności procesu } \\
\text { zawirowania mieszanki }\end{array}$ & $\begin{array}{l}\text { Zmniejszenie emisji cząstek stałych przy nie nara- } \\
\text { stającej emisji tlenków azotu }\end{array}$ \\
\hline 3. & Elektronizacja procesu wtrysku & $\begin{array}{l}\text { Uzależnienie kąta wyprzedzenia wtrysku i dawki } \\
\text { paliwa od większej ilości parametrów istotnych } \\
\text { dla procesu spalania i jego efektów }\end{array}$ \\
\hline 4. & Doładowanie silnika & $\begin{array}{l}\text { Obniżenie emisji toksycznych składników spalin, } \\
\text { wzrost sprawności }\end{array}$ \\
\hline 5. & Chłodzenie doładowanego powietrza & $\begin{array}{l}\text { Podwyższenie efektów wynikających z procesu } \\
\text { doładowania }\end{array}$ \\
\hline 6. & $\begin{array}{l}\text { Zmniejszenie wartości kąta wyprze- } \\
\text { dzenia wtrysku }\end{array}$ & $\begin{array}{l}\text { Obniżenie emisji tlenków azotu, ekwiwalentne } \\
\text { skrócenie czasu wtrysku oraz opóźnienie samo- } \\
\text { zapłonu }\end{array}$ \\
\hline 7. & Chłodzenie doładowanego powietrza & $\begin{array}{l}\text { Zwiększenie efektów wynikających z procesu } \\
\text { doładowania }\end{array}$ \\
\hline 8. & $\begin{array}{l}\text { Instalowanie katalizatora przyspiesza- } \\
\text { jącego proces utleniania }\end{array}$ & $\begin{array}{l}\text { Obniżenie emisji cząstek stałych, węglowodorów } \\
\text { i tlenku węgla }\end{array}$ \\
\hline 9. & Instalowanie filtrów sadzy & $\begin{array}{l}\text { Obniżenie emisji cząstek stałych oraz wpływ na } \\
\text { zmniejszenie emisji węglowodorów }\end{array}$ \\
\hline 10. & $\begin{array}{l}\text { Instalowanie urządzeń skracających } \\
\text { czas nagrzewania silnika }\end{array}$ & $\begin{array}{l}\text { Obniżenie toksyczności spalin w procesie nagrze- } \\
\text { wania }\end{array}$ \\
\hline 11. & $\begin{array}{l}\text { Zmniejszanie zużycia oleju silniko- } \\
\text { wego }\end{array}$ & $\begin{array}{l}\text { Zmniejszenie emisji cząstek stałych, węglowodo- } \\
\text { rów, w tym wielopierścieniowych }\end{array}$ \\
\hline 12. & $\begin{array}{l}\text { Podgrzewanie paliwa w trakcie uru- } \\
\text { chamiania }\end{array}$ & $\begin{array}{l}\text { Obniżenie toksyczności spalin, zmniejszanie } \\
\text { zużycia paliwa }\end{array}$ \\
\hline 13. & $\begin{array}{l}\text { Stosowanie paliw o obniżonej zawar- } \\
\text { tości siarki }\end{array}$ & $\begin{array}{l}\text { Obniżenie zawartości związków siarki w spa- } \\
\text { linach, obniżenie emisji cząstek stałych oraz } \\
\text { wydłużenie czasu aktywności katalizatora }\end{array}$ \\
\hline 14. & $\begin{array}{l}\text { Chłodzenie komory spalania określo- } \\
\text { ną ilością wody }\end{array}$ & Obniżenie emisji tlenków azotu \\
\hline
\end{tabular}


Prowadzone działania perspektywiczne w silnikach o zapłonie iskrowym, realizowane dla zmniejszenia zużycia paliwa i obniżenia toksyczności spalin realizowane są przez sterowanie procesem zasilania paliwem, w taki sposób, aby możliwe było spalanie mieszanek ubogich. W procesie tym stosowane są następujące rozwiązania:

- wzbogacanie mieszanek dwufazowych w obszarze otaczającym świece, a jednofazowych w obszarze zapłonu;

- kształtowanie układu dolotowego w taki sposób, aby przez odpowiednie ukształtowanie konstrukcji tego układu było możliwe uzyskanie dużego zawirowania, turbulencji przepływu ładunku oraz doładowanie dynamiczne;

- wprowadzanie nowych rozwiązań układów zasilania jak np.:

- elektronizację procesu wytwarzania mieszanki w unowocześnionych systemach klasycznych (Carburator-CARB);

- stosowanie centralnego, jednopunktowego, niskociśnieniowego wtrysku paliwa do kolektora dolotowego (Single Point Injection - SPI);

- stosowanie wielopunktowego, niskociśnieniowego wtrysku paliwa do króćców dolotowych (Multi Point Injection - MPI);

- stosowanie niskociśnieniowego wtrysku do cylindra poprzez szczeliny dolotowe w silnikach dwusuwowych (Semi Direct Injection - SDI);

- stosowanie wtrysku mieszanki bezpośrednio do cylindrów (Direct Mixture Injection - DMI);

- stosowanie wysokociśnieniowego wtrysku bezpośredniego paliwa lekkiego do cylindra (Gazoline Direct Injection - GDI).

W silnikach o zapłonie samoczynnym, zasadniczymi elementami konstrukcyjnymi, których działanie wpływa na zużycie paliwa i obniżenie toksyczności spalin są systemy spalania, kształt komór dolotowych i przestrzeni spalania oraz systemy wtrysku paliwa.

Jak już wspomniano prowadzone są prace badawcze, których wyniki częściowo są już wdrażane, w zakresie budowy i eksploatacji nowych źródeł napędu. Do tych źródeł zaliczyć można:

- silniki dwusuwowe nowej generacji;

- turbiny gazowe nowej generacji;

- ogniwa paliwowe;

- napędy elektryczne;

- napędy hybrydowe;

- silniki o spalaniu zewnętrznym (silnik Stirlinga i silnik Ericssona).

Silniki dwusuwowe stosowane były dotychczas głównie w technice jako silniki wolnoobrotowe dużej mocy. Zastosowanie tych silników do napędu samochodów z racji chociażby ich prostszej konstrukcji, bardziej równomiernej pracy, wysokiej sprawności, a przede wszystkim mniejszej emisji związków toksycznych w rozwiązaniach nowej generacji wymaga jeszcze rozwiązania kilku problemów. 
Do najistotniejszych zaliczyć można konieczność oddzielenia mieszanki od gazów spalinowych, wybór właściwego systemu smarowania, wybór systemu rozrządu itp.

Turbiny gazowe dotychczas nie byly stosowane w napędach samochodowych z powodu niskiej sprawności sięgającej $20 \%$ oraz dużej zależności tej sprawności od obciążenia. Współczesne turbiny osiągają sprawności do $40 \%$ i są dostosowane do wyższych temperatur pracy poprzez wprowadzenie ceramicznych wirników tych turbin, a także pracy w układach hybrydowych przy mocach zblizonych do mocy znamionowych.

Ogniwa paliwowe jako źródła napędu charakteryzują się wysoką sprawnością energetyczną i brakiem ujemnego działania na środowisko. Zachodzące w nich procesy zamiany energii wewnętrznej (chemicznej) na energię elektryczną powodują, w przeciwieństwie do konwencjonalnych źródeł, bezpośrednią konwersję tej energii. Stąd też przekształcenie energii chemicznej w elektryczną z powodu małej zmiany entropii reakcji w porównaniu z ciepłem tej reakcji odbywa się z wysoka sprawnością. Paliwami (utleniaczami) w ogniwach mogą być substancje gazowe typu wodór, amoniak, metan, powietrze lub alkohole, hydrazyna, ciekłe węglowodory, a nawet węgiel. Ze względu na rodzaj elektrolitu ogniwa paliwowe dzielą się na:

- zasadowe (AFC);

- fosforowe (PAFC);

- węglanowe (MCFC);

- polimerowe (PEFC);

- wykorzystujące tlenki metali (SOFC).

Ogniwa paliwowe mają różne temperatury i ciśnienia pracy zawierające się od temperatury otoczenia i ciśnienia atmosferycznego do wysokich temperatur i ciśnień. Badania amerykańskie potwierdzają opłacalność stosowania ogniw paliwowych jako źródła energii dla silników elektrycznych napędzających samochody pod warunkiem stosowania ogniw o koszcie wytwarzania $1 \mathrm{~kW}$ poniżej 50 USD. W chwili obecnej ogniwa paliwowe znajdują duże zastosowanie w napędach hybrydowych.

Pewną nowością jest wykorzystanie paliw węglowodorowych w zasilaniu ogniw paliwowych polegające na spalaniu par paliwa z małą ilością powietrza prowadzące $\mathrm{z}$ wytworzeniem tlenku węgla i wodoru. Ciepło reakcji jest wykorzystywane do dodatkowego, katalitycznego wytwarzania wodoru i ditlenku węgla. W efekcie prowadzonego tak procesu, pozostały węgiel osadzać się będzie na filtrach, a niska temperatura procesu uniemożliwi powstawanie tlenków azotu.

Wykorzystanie energii elektrycznej bezpośrednio czerpanej z baterii lub akumulatorów nie jest przewidywane jako źródło napędu, $\mathrm{z}$ uwagi na wagę i pojemność elektryczną tych urządzeń. W efekcie napęd elektryczny uwzględniany jest w układach hybrydowych umożliwiających wykorzystywanie energii hamowania. 
Napędy hybrydowe są coraz częściej stosowane w samochodach ze względu na znaczne zmniejszenie jednostkowego zużycia energii wraz z redukcją do minimalnego poziomu stopnia zanieczyszczania środowiska. Napędy hybrydowe mające dwa źródła napędu mogą pracować w układach szeregowych lub równoległych wykorzystując: silnik spalinowy, wysokosprawną, ceramiczną turbinę gazową, ogniwa paliwowe i maszyny elektryczne (silnik i prądnicę).

Najnowszymi rozwiązaniami jednostek napędowych są silniki o spalaniu zewnętrznym. Należą do nich silnik Sterlinga o obiegu izotermiczno-izochorycznym, który może być wykorzystywany w układach tłokowych oraz podobnie działający silnik Ericssona, izobaryczno-izotermiczny do wykorzystania w turbinach.

\section{Prognoza rozwoju paliw standardowych do silników spalinowych}

Rozwój i modyfikacje napędów współczesnych silników wymagają także rozwoju paliw do tych napędów, tak aby spełnione zostały wymagania związane z procesami zasilania, odparowania, spalania i odprowadzania spalin w silnikach oraz wymagania związane $z$ ochroną środowiska, transportem, magazynowaniem i dystrybucją paliw. Zatem paliwa muszą odpowiadać wymuszeniom ze strony urządzeń je spalających. Wymuszenia te określają konstruktorzy i producenci pojazdów, gwarantując jednocześnie trwałość i niezawodność silników zasilanymi odpowiednimi dla niego paliwami.

Dla zapewnienia właściwej jakości paliw do silników o zapłonie iskrowym i samoczynnym, spełniające wymagania silników spalinowych i ochrony środowiska, czołowe, światowe koncerny samochodowe powołały Komitet do Spraw Światowej Karty Paliw (World-Wide Fuel Charter -WWFC). W skład Komitetu weszli jako czlonkowie przedstawiciele takich organizacji jak:

- ACEA (Association des Constructeurs Europeens d'Automobiles Europejskie Zrzeszenie Producentów Samochodów);

- Alliance of Automobile Manufacturers (Stowarzyszenie Producentów Samochodów)

- EMA (Engine Manufactureres Association - Zrzeszenie Producentów Silników);

- JAMA (Japanese Automobile Manufactureres Association - Japońskie Zrzeszenie Producentów Samochodów).

Poza wymienionymi organizacjami w skład Komitetu weszli także przedstawiciele AIAM (Association of International Automobile Manufacturers Międzynarodowego Zrzeszenia Producentów Samochodów) oraz następujących narodowych stowarzyszeń producentów samochodów i silników;

- kanadyjskiego zrzeszenia producentów samochodów (AIAMC) i zrzeszenia producentów pojazdów (CVMA); 
- meksykańskiego zrzeszenia przemysłu motoryzacyjnego (AMIA);

- filipińskiej izby producentów samochodów (CAMPI);

- brazylijskiego zrzeszenia producentów silników i samobieżnych maszyn rolniczych (ANFAVEA);

- chińskiego zrzeszenia przemysłu motoryzacyjnego (CAAI);

- koreańskiego zrzeszenia producentów samochodów (KAMA);

- południowo-afrykańskiego zrzeszenia przemysłu motoryzacyjnego (NAAMSA);

- tajskiego zrzeszenia przemysłu motoryzacyjnego (TAIA).

Organizacją wspierającą działania Komitetu była także OICA (Organisation Internationale des Constructeurs d'Automobiles - Międzynarodowa Organizacja Konstruktorów Samochodów).

Aktualnie obowiązująca edycja Światowej Karty Paliw obowiązuje od grudnia 2002 r. Dzieli ona paliwa na cztery kategorie zarówno w grupie paliw do silników o zapłonie iskrowym jak i też samoczynnym.

W kategorii 1 zestawiono wymagania dla paliw stosowanych na rynkach bez żadnych, albo z minimalnymi wymaganiami, co do kontroli emisji szkodliwych składników spalin, spełniających głównie podstawowe wymagania silników i samochodów.

Kategoria 2 obejmuje paliwa użytkowane na rynkach o ostrzejszych wymaganiach ogólnych jak i tez z zakresu ochrony środowiska. W tej kategorii znajdują się paliwa spełniające wymagania US Tier 0 lub 1, EURO 1 i 2 lub równoważne wymagania z zakresu norm emisyjności toksycznych składników spalin.

W kategorii 3 mieszczą się paliwa przeznaczone na rynki o zaostrzonymi wymaganiami ogólnymi i z zakresu ograniczania emisji toksycznych składników spalin spełniające wymagania US California LEV, ULEV, EURO 3 i 4 lub równoważne wymagania co do emisyjności toksycznych składników spalin.

Ostatnia kategoria 4 obejmuje paliwa o najbardziej zaostrzonych wymaganiach jakościowych, szczególnie z zakresu emisji, łącznie z zaawansowanymi sposobami redukcji tlenków azotu i cząstek stałych ze spalin. Paliwa te musza spełniać wymagania US California LEV-II, US EPA Tier 2, EURO 4 lub równoważne standardy tym wymaganiom, a także muszą być określone wymagania z zakresu ograniczania zużycia paliwa.

W stosunku do paliw spełniających wymagania Światowej Karty Paliw określają wymagania dla produktu gotowego. Jeżeli zatem paliwo spełnia te wymagania to nie należy określać i wprowadzać dodatkowych wymagań i metod kontroli pośredniej lub wewnętrznej.

Wymagania Światowej Karty Paliw dla paliw do silników o zapłonie iskrowym przedstawiono w tablicy 4 . 
Tablica 4. Wymagania dla paliw do silników o zapłonie iskrowym według Swiatowej Karty Paliw

\begin{tabular}{|c|c|c|c|c|c|c|c|}
\hline \multirow{2}{*}{\multicolumn{3}{|c|}{ Parametr }} & \multirow{2}{*}{$\begin{array}{l}\text { Jedn. } \\
\text { miary }\end{array}$} & \multicolumn{4}{|c|}{ Kategoria } \\
\hline & & & & 1 & 2 & 3 & 4 \\
\hline & B & LOM & & \multicolumn{4}{|l|}{91,0} \\
\hline & 91 & LOB & & \multicolumn{4}{|l|}{82,5} \\
\hline \multicolumn{2}{|c|}{ Liczba oktanowa (min.) } & LOM & - & \multicolumn{4}{|l|}{95,0} \\
\hline & 95 & LOB & & \multicolumn{4}{|l|}{85,0} \\
\hline & $\mathrm{B}$ & LOM & & \multicolumn{4}{|l|}{98.0} \\
\hline & 98 & LOB & & \multicolumn{4}{|l|}{88,0} \\
\hline \multicolumn{3}{|c|}{ Stabilność oksydacyjna (min.) } & $\min$. & 360 & \multicolumn{3}{|l|}{480} \\
\hline \multicolumn{3}{|c|}{ Zawartość siarki (max.) } & $\mathrm{mg} / \mathrm{kg}$ & $1000^{(1)}$ & 200 & 30 & $0^{(2)}$ \\
\hline \multicolumn{3}{|c|}{ Zawartość metali (Fe, $\mathrm{Mn} \mathrm{Pb}^{(3)} \mathrm{i}$ innych) } & $\mathrm{g} / \mathrm{l}$ & \multicolumn{4}{|c|}{ niewykrywalna ${ }^{(4)}$} \\
\hline \multicolumn{3}{|l|}{ Zawartość fosforu } & $\mathrm{g} / \mathrm{l}$ & - & \\
\hline \multicolumn{3}{|l|}{ Zawartość krzemu } & $\mathrm{g} / \mathrm{kg}$ & - & \multicolumn{3}{|c|}{ niewykrywalna $^{(4)}$} \\
\hline \multicolumn{3}{|c|}{ Zawartość tlenu (max.) } & $\%(\mathrm{~m} / \mathrm{m})$ & \multicolumn{4}{|l|}{$2,7^{(5)}$} \\
\hline \multicolumn{3}{|c|}{ Zawartość olefin (max.) } & $\%(\mathrm{v} / \mathrm{v})$ & - & 20,0 & \multicolumn{2}{|c|}{10,0} \\
\hline \multicolumn{3}{|c|}{ Zawartość aromatów (max.) } & $\%(\mathrm{v} / \mathrm{v})$ & 50,0 & 40,0 & 35,0 & \\
\hline \multicolumn{3}{|c|}{ Zawartość benzenu (max.) } & $\%(\mathrm{v} / \mathrm{v})$ & 5,0 & 2,5 & 1.0 & \\
\hline \multicolumn{3}{|l|}{ Lotność } & \multicolumn{5}{|c|}{$\begin{array}{l}\text { klasy w zależności od min. temp. oto- } \\
\text { czenia }\end{array}$} \\
\hline \multicolumn{3}{|c|}{ Zawartość osadów (max.) } & $\mathrm{mg} / \mathrm{l}$ & - & 1 & & \\
\hline Zawartość żywic ni & nywaln & & $\begin{array}{l}\mathrm{mg} / \\
100 \mathrm{ml}\end{array}$ & 70 & $70^{(6)}$ & $30^{(6)}$ & \\
\hline Zawartość żywic ol & h $(\max$ & & $\begin{array}{l}\mathrm{mg} / \\
100 \mathrm{ml}\end{array}$ & 5 & & & \\
\hline Gęstość & & & $\mathrm{kg} / \mathrm{m}^{3}$ & $\begin{array}{l}715- \\
-780 \\
\end{array}$ & $715 \ldots$ & & \\
\hline Korozja na miedzi & & & wzorzec & klasa I & & & \\
\hline Wygląd & & & - & przejrzy & sty i ja & & \\
\hline Czystość gaźnika & & & wzorzec & $8,0^{(7)}$ & - & - & - \\
\hline Czystość wtryskiwa & liwa (n & & $\begin{array}{l}\text { \%zmn. } \\
\text { przepł. }\end{array}$ & $10^{(7)}$ & 5 & & \\
\hline Test na zawieszanie & woru w & & - & - & spełn & testu & \\
\hline Czystość zaworu w & go I (m & & wzorzec & $9,0^{(7)}$ & - & - & - \\
\hline Czystość zaworu & wg. $\mathrm{Cl}$ & -93 & $\begin{array}{l}\mathrm{mg} / \mathrm{za}- \\
\text { wór }\end{array}$ & - & 50 & 30 & \\
\hline wlotowego & lub AS & & $\begin{array}{l}\text { (śred- } \\
\text { nio) }\end{array}$ & - & 100 & 50 & \\
\hline II (max.) & lub AS & & & - & 90 & 50 & \\
\hline Osady & wg. As & & $\begin{array}{l}\text { \%paliwa. } \\
\text { baz. }\end{array}$ & - & 140 & 140 & \\
\hline w komorze & lub CF & -98 & $\begin{array}{l}\mathrm{mg} / \mathrm{sil}- \\
\mathrm{nik}\end{array}$ & - & 3500 & 250 & \\
\hline $\operatorname{spalania}^{(6)}(\max )$. & lub TC & BZI5401 & $\begin{array}{l}\%(\mathrm{~m} / \mathrm{m} .) \\
\mathrm{w} \\
450^{\circ} \mathrm{C}\end{array}$ & - & 20 & & \\
\hline
\end{tabular}




\section{Legenda:}

(1) do napędu samochodów wyposazonych w katalizator dopalania spalin zalecane jest paliwo o niższej zawartości siarki.

(2) dopuszczalny zakres zawartości siarki (5...10) $\mathrm{mg} / \mathrm{kg} w$ zależności od przyjętych standardów emisyjności.

(3) nie dopuszcza się świadomego wprowadzania. Zawartość Pb do $0,005 \mathrm{~g} / \mathrm{l}$ jest dopuszczalna wokresie przejściowym.

(4) na granicy lub ponizej wykrywalności stosowanej metody oznaczania. Wyklucza się możliwość świadomego wprowadzania. Dopuszcza się zawartość dodatków zawierajacych metale dla ochrony gniazd zaworowych w samochodach zasilanych benzynami kategorii 1, nie posiadajacych katalizatorów dopalania spalin. W tym przypadku zalecane sq dodatki na bazie potasu.

(5) w przypadku wprowadzania zwiazków tlenowych, zaleca się stosowanie eterów. Wymagania normy zezwalaja na dodawanie do $10 \%(v / v)$ etanolu (ASTM D 4806, pH =6,5...9. Tak sporzadzona mieszanka musi jednak spełniać wszelkie pozostałe wymagania dla danej kategorii. Alkohole wyższe, (powyżej $C_{2}$ ) moga być dodawane nie więcej niż $0,1 \%(v / v)$. Nie dopuszcza się dodawania metanolu.

(6) dopuszcza się spetnienie zgodnie z wymaganiami dla danej kategorii paliwa wymagań dla parametru „żwice nieprzemywalne” lub „osady w komorze spalania”

(7) zgodność z wymaganiem określa się przy zastosowaniu wlaściwych dodatków detergencyjnych do porównywalnej benzyny bazowej.

Wymagania zawarte w Światowej Karcie Paliw dla paliw do silników o zapłonie iskrowym wskazują na następujące najważniejsze tendencje w rozwoju tych paliw związane z wymaganiami silników i pojazdów:

Ograniczenie zawartości siarki w paliwach, co jest związane z toksycznymi dla środowiska produktami jej spalania oraz skłonnością do zatruwania katalizatora spalin, co zmniejsza możliwość redukcji ilości węglowodorów i tlenków azotu zawartych w spalinach. Dodatkowo obecność siarki obniża skuteczność technologii eliminacji tlenków azotu w perspektywicznych rozwiązaniach bazujących na spalaniu mieszanek ubogich (oszczędność zużycia paliwa).

Eliminacji zawartości związków ołowiu.

Eliminacji dodatków mogących wpływać na powstawanie popiołu.

Eliminacji zawartości związków metaloorganicznych podwyższających liczbę oktanową typu metylocyklopentadienylo trikarbonylku manganu (MMT) lub ferrocenów zawierających żelazo. Aktualnie prowadzone są badania określające wpływ związków manganu na efektywność działania katalizatorów, to jednak zakłada się że związki te podobnie jak związki żelaza odkładać się będą na powierzchni katalizatora, a tym samym wzrośnie zawartość toksycznych składników w spalinach.

Eliminacji zawartości krzemu i jego związków, które mogą być wprowadzone do paliw poprzez blendowanie ich ze zużytymi, różnymi rozpuszczalnikami, powodując uszkodzenia czujników wykrywaczy tlenu i katalizatora dopalania spalin.

Ograniczenia wprowadzania do benzyn związków tlenowych typu eterów lub etanolu i alkoholi wyższych, przy jednoczesnym zakazie wprowadzania do paliw metanolu. Ograniczenie to spowodowane jest pogorszeniem właściwości jezdnych i mało skutecznym zmniejszaniem emisji tlenków azotu w silnikach za- 
silanych mieszankami ubogimi. Stwierdzono także w badaniach, że w procesie spalania benzyn z dodatkiem $10 \%$ etanolu, emisja toksycznych substancji obniżyła się o $2 \%$, a emisja tlenku węgla o $10 \%$ w porównaniu z benzyną zawierającą 11\% MTBE, ale emisja tlenków azotu wzrosła o 14\%, węglowodorów o $10 \%$ oraz potencjał tworzenia ozonu o $9 \%$. A zatem przy wprowadzaniu do benzyn alkoholi nie powinno się wprowadzać dodatkowo eterów. Zakaz wprowadzania metanolu wynika z moźliwości spowodowania korozji części metalowych i degradacji komponentów plastycznych i elastomerów.

Ograniczenie zawartości olefin (węglowodorów nienasyconych), mimo ich wpływu na podwyższanie liczby oktanowej, spowodowane możliwością tworzenia żywic i wytracania się osadów, a także wzrostu emisji reaktywnych węglowodorów powodujących możliwość powstawania ozonu i związków toksycznych.

Ograniczanie zawartości węglowodorów aromatycznych wpływających na odkładanie się osadów w silniku i zwiększoną emisyjność spalin, w tym ditlenku węgla.

Ograniczenie zawartości benzenu ze względu na jego silne działanie rakotwórcze.

Powiązanie temperatur odparowania $10 \%, 50 \%, 90 \%$ paliwa $w$ destylacji normalnej (odpowiednio T10, T50 i T90) i procentowej zawartości związków tlenowych w paliwie (\%OXY) w indeks właściwości jezdnych (DI) w zależność: $\mathrm{DI}=1,5 \mathrm{~T} 10+3 \mathrm{~T} 50+\mathrm{T} 90+11 \% \mathrm{OXY}$. Wyższe wartości DI niż 550-570 pogarszają się znacznie właściwości jezdne, przy wzroście emisji weglowodorów.

W tablicy 5 zestawiono wymagania Światowej Karty Paliw dla wszystkich kategorii paliw do silników o zapłonie samoczynnym.

Tablica 5. Wymagania dla paliw do silników o zapłonie samoczynnym według Światowej Karty Paliw

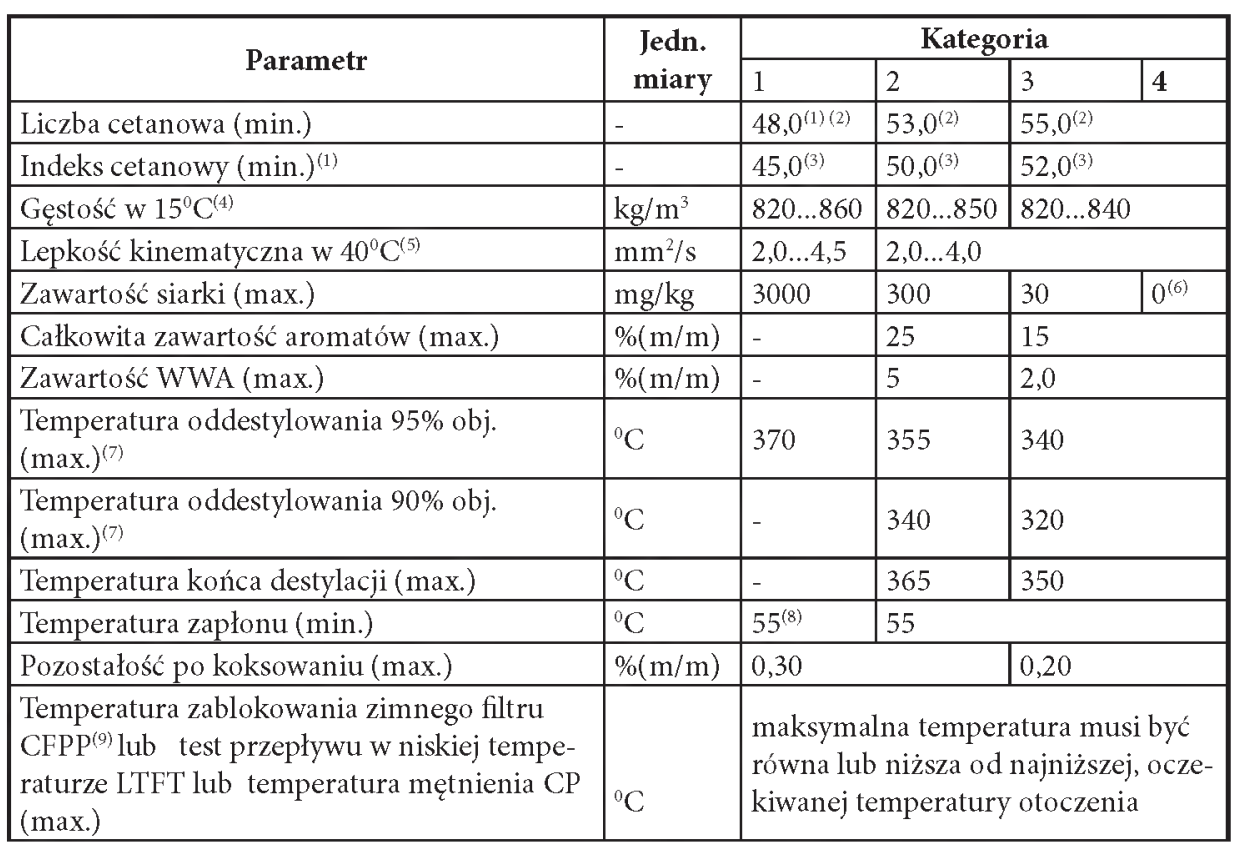


Krzysztof Biernat

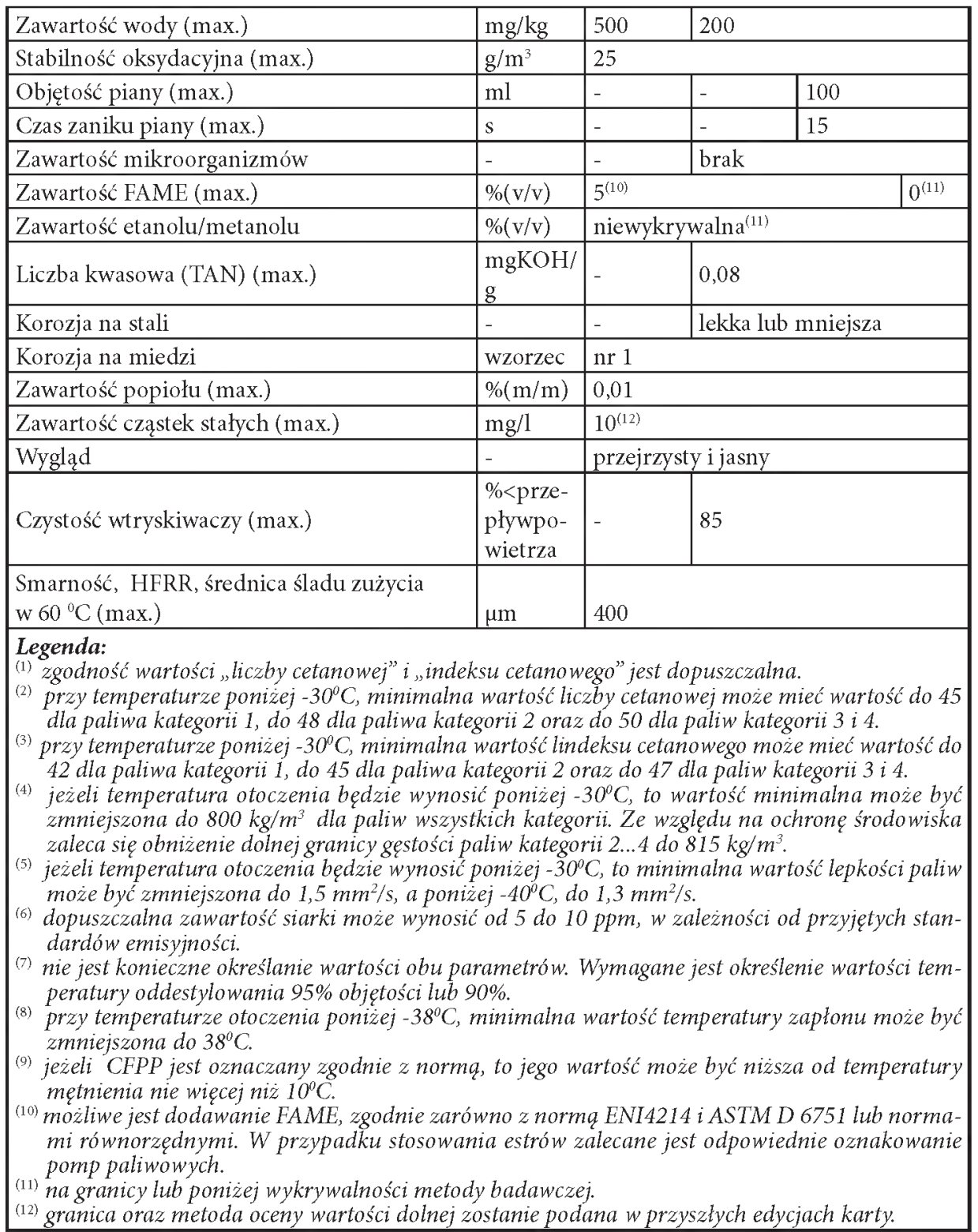

Podane w tablicy 5 wymagania dla paliw do silników o zapłonie samoczynnym wskazują na następujące tendencje w rozwoju tych paliw:

Dla uniknięcia nadmiernego stosowania dodatków podwyższających liczbę cetanową ustala się minimalną różnicę pomiędzy tą liczbą, a indeksem cetanowym (CI, CCI). Indeks cetanowy, charakteryzujące także właściwości samozapłonowe paliw, wyznacza się z następujących zależności: 
Według normy ASTM D976-80:

$\mathrm{CI}=454,74-1641,416 \mathrm{D}+774 \mathrm{D}^{2}-0,554 \mathrm{~B}+97,803(\lg \mathrm{B})^{2}$ gdzie:

- D - gęstość paliwa w temperaturze $15^{\circ} \mathrm{C}$;

- B - temperatura oddestylowania 50\% (v/v) paliwa $\mathrm{w}^{\circ} \mathrm{C}$.

Drugi, bardziej złożony sposób obliczania indeksu cetanowego (CCI), według ASTM D4737-87, wymaga określenia gęstości paliwa oraz temperatur oddestylowania 10, 50 i 90\% objętościowych paliwa i jest obliczany z zależności: $\mathrm{CCI}=45,2+(0,0892)\left(\mathrm{T}_{10 \mathrm{~N}}\right)+[0,13]+(0,901)(\mathrm{B})\left(\mathrm{T}_{50 \mathrm{~N}}\right)+[0,0523-(0,0420)(\mathrm{B})]\left[\mathrm{T}_{90 \mathrm{~N}}\right]+$ $+[0,00049]\left[\left(\mathrm{T}_{10 \mathrm{~N}}\right)^{2}-\left(\mathrm{T}_{90 \mathrm{~N}}\right)^{2}\right]+(107)(\mathrm{B})+(60)(\mathrm{B})^{2}$ gdzie:

- $\mathrm{B}=\left[\mathrm{e}^{(-3,5)(\mathrm{DN})}\right]-1$;

- $\mathrm{DN}=\mathrm{D}-0,85$;

- D - gęstość paliwa w $15^{\circ} \mathrm{C}$;

- $\mathrm{T}_{10}$ - temperatura oddestylowania $10 \%(\mathrm{v} / \mathrm{v})$ paliwa $\mathrm{w}^{\circ} \mathrm{C}$;

- $\mathrm{T}_{10 \mathrm{~N}}=\mathrm{T}_{10}-215$;

- $\mathrm{T}_{50}-$ temperatura oddestylowania $50 \%(\mathrm{v} / \mathrm{v})$ paliwa $\mathrm{w}^{\circ} \mathrm{C}$;

- $\mathrm{T}_{50 \mathrm{~N}}=\mathrm{T}_{50}-260$;

- $\mathrm{T}_{90}$ - temperatura oddestylowania $90 \%(\mathrm{v} / \mathrm{v})$ paliwa $\mathrm{w}^{\circ} \mathrm{C}$;

- $\mathrm{T}_{90 \mathrm{~N}}=\mathrm{T}_{90}-310$.

Ten drugi sposób obliczania indeksu cetanowego (CCI) jest aktualnie przyjmowany jako obowiązujący w normach.

Ustala się zakres wartości gęstości dla poszczególnych kategorii paliw, który wynika z badań określających korelację wpływu obniżenia gęstości na obniżenie emisji cząstek stałych i tlenków azotu z silników mocno obciążonych przy jednoczesnym spadku mocy i zwiększeniu zużycia paliwa.

Ustala się zakres wartości lepkości paliwa wynikający z badań nad procesem wtrysku paliwa i stopniem napełnienia, zależnym od tej wartości, przy jednoczesnym wykładniczym spadku wartości lepkości spowodowanym wzrostem temperatury.

Ze względu na to, że siarka zawarta w paliwach poza tworzeniem w procesie spalania tlenków siarki, podwyższa znacznie emisję cząstek stałych, stymuluje procesy korozji niskotemperaturowej oraz zatruwa adsorbery tlenków azotu w silnikach nowej generacji znacznemu ograniczeniu podlega jej zawartość, aż do całkowitego wyeliminowania jej zawartości w paliwach kategorii 4 .

Ogranicza się zawartość węglowodorów aromatycznych niezależnie od ich niskich wartości liczby cetanowej. Spowodowane to jest tym, że zwiększając skłonność do pracy twardej silników, powodują wzrost emisji cząstek stałych (zadymienie spalin) oraz wpływają na wzrost emisji wielopierścieniowych węglowodorów aromatycznych (WWA) w spalinach.

Ze względu na wpływ niższych wartości temperatury oddestylowania 90 lub 95\% (v/v) paliwa na mniejszą emisję tlenków azotu przy jednoczesnej tendencji do wzrostu emisji węglowodorów, w gazach spalinowych silników wysoko obciążonych i redukcję emisji cząstek stałych oraz wzroście emisji tlenków azotu dla lekko obciążo- 
nych silników, ustala się optymalne wartości tych temperatur wynikające z badań.

Jeżeli właściwości niskotemperaturowe paliw do silników o zapłonie samoczynnym będą określane przy pomocy oznaczania temperatury mętnienia (CPCloud Point) lub obowiązującym w USA i Kanadzie teście na płynność paliwa w niskich temperaturach (LTFT - Low Temperature Flow Test) to wartość tej temperatury powinna być dla paliwa wyższa niż najniższa, przewidywana temperatura otoczenia. W przypadku określania temperatury zablokowania zimnego filtra (CFPP - Cold Flow Plugging Point)) to maksymalna wartość CFPP powinna być równa lub niższa od najniższej, przewidywanej temperatury otoczenia, przy czym wartość ta nie może wynosić więcej niż $10^{\circ} \mathrm{C}$ od ustalonej wartości CFPP od ustalonej w Karcie wartości dla danej kategorii paliwa.

Ogranicza się zawartość estrów pochodzenia roślinnego, głównie FAME (fatty acid methyl esters - estrów metylowych kwasów tłuszczowych) w olejach napędowych z powodu ich niekorzystnych właściwości niskotemperaturowych, higroskopijności, większej tendencji do tworzenia osadów i agresywnego oddziaływania na uszczelnienia i niektóre elementy układu paliwowego.

Wprowadza się badanie czystości wtryskiwaczy zależnej miedzy innymi od ilości i rodzaju wprowadzanych detergentów jako dodatków, ze względu na prawidłowy przebieg procesu rozpylania paliwa.

Ze względu na konieczność zapewnienia właściwej pracy pompy wtryskowej, przy jednoczesnym eliminowaniu zawartości siarki w paliwach, określa się smarność paliw poprzez badanie w urządzeniu testowym HFRR (High Frequency Reciprocating Rig - urządzenie tłokowe o wysokiej częstotliwości ruchu posuwisto-zwrotnego), normując ją w temperaturze $60^{\circ} \mathrm{C}$.

\section{Rozwój wymagań stawianych olejom i cieczom opałowym}

Konstrukcje urządzeń grzewczych dla ciepłownictwa posiadają swoją specyfikę, narzucającą określone wymagania w stosunku do olejów i cieczy opałowych. Zdecydowana większość tych urządzeń, zwłaszcza małej mocy, wraz ze zbiornikami na paliwo, sytuowana jest w podziemiach i parterowych kondygnacjach ogrzewanych obiektów. Oleje opałowe przechowywane w odpowiednich zbiornikach magazynowych, uzupełnianych 1-2 razy na rok, nie mogą więc zawierać substancji łatwopalnych, wybuchowych czy cuchnących. Ograniczenia palności zdefiniowane są temperaturą zapłonu (nie niżej $55^{\circ} \mathrm{C}$ ). Najkorzystniej $\mathrm{z}$ tego punktu widzenia poza opałowymi olejami standardowymi przedstawiają się oleje roślinne (temperatura zapłonu powyżej $295^{\circ} \mathrm{C}$ ) oraz oleje zużyte, niepoprawnie nazywane olejami przepracowanymi. Olej zużyty (used oil) jest to taki olej smarowy, który na skutek działania na niego wymuszeń termochemicznych i mechanicznych ze strony smarowanego skojarzenia lub węzła tarcia zatracił część lub całość właściwości eksploatacyjnych w danym skojarzeniu lub węźle 
(termin oleje przepracowane, jest typowym rusycyzmem: „ot'rabotannyje masła”, pochodzącym z bezpośredniego tłumaczenia norm GOST na Polskie Normy).

Zdecydowanie niższą temperaturę zapłonu, niż oleje lekkie pochodzenia naftowego, wykazują destrukty termiczne olejów zużytych i roślinnych. Jeszcze niższą - alkohole, co zdecydowanie ogranicza możliwość ich praktycznego wykorzystania w omawianym zakresie..

Brak jest powszechnie stosowanych metod oceny zapachu ciekłych paliw, szczególnie niestandardowych. Instrumentalnie określa się (metodą chromatograficzną) stężenie substancji lub ich grup odpowiedzialnych za odoryzację oparów. Najczęściej jednak ocenę taką prowadzi się metodą organoleptyczną. Naftowe oleje opałowe wykazują stosunkowo niską lotność i umiarkowaną uciążliwość zapachową. Zdecydowanie niekorzystne właściwości zapachowe wykazują oleje zużyte, produkty ich termicznej destrukcji i niektóre odpadowe węglowodory. Najkorzystniejszą charakterystykę zapachową (bardzo niska lotność par) wykazują świeże oleje roślinne i produkty ich metanolizy. Jednakże długotrwałe przechowywanie może pogarszać ich właściwości zapachowe.

Lokalizacja zbiorników paliwowych w pomieszczeniach nie ogrzewanych (co jest oczywiste ze względów pożarowych), a niekiedy na zewnątrz budynków narzuca określone wymagania na właściwości niskotemperaturowe cieczy opałowych. Definiują one bowiem ich płynność a więc możliwość transportu paliw do zbiorników magazynowych i stąd do palników. W przypadkach niekorzystnych właściwości niskotemperaturowych olejów i cieczy opałowych zachodzi potrzeba zastosowania depresatorów lub urządzeń podgrzewających. Gorsze właściwości niskotemperaturowe od olejów naftowych wykazują oleje roślinne i ich estry. Zdecydowanie najkorzystniejszą charakterystykę niskotemperaturową posiadają alkohole.

Długotrwały okres przechowywania olejów i cieczy opałowych sprzyja, szczególnie przy ich niskiej stabilności chemicznej, sedymentacji różnego rodzaju osadów i wody. Gromadzące się na dnach zbiorników szlamy mogą wywoływać procesy korozji i niedrożność aparatury paliwowej. Jest to przyczyną uciążliwych operacji napraw i czyszczenia instalacji paliwowych urządzeń ciepłowniczych. Dlatego też stabilność i czystość cieczy opałowych dla ciepłownictwa jest zagadnieniem niezwykle ważnym i niestety - bardzo często niedocenianym.

Praca olejowych urządzeń grzewczych sterowana jest na ogól automatycznie. Stąd też uruchomiane są okresowo w miarę zapotrzebowania na ciepło. Warunki pracy kotłów, szczególnie w okresie ich uruchomiania sprzyjają zwiększonej emisji sadzy i innych produktów niepełnego spalania komponentów paliwa. Szczególnie niebezpieczne w tym zakresie są węglowodory aromatyczne oraz wszelkiego typu związki heterocykliczne, a zwłaszcza chloropochodne. W takich warunkach lub przy zbyt niskiej temperaturze w paleniskach prawdopodobne jest powstawanie związków poliaromatycznych i dioksyn.

Stąd też obecność w olejach i cieczach opałowych substancji prowadzących do tego typu zjawisk jest niedopuszczalna, mimo iż przedmiotowe normy tego 
wprost nie definiują. Szczególnie dokładna kontrola spalin musi być prowadzona w przypadku spalania cieczy opałowych otrzymywanych na bazie olejów zużytych, nawet jeśli urządzenia grzewcze są do tego przystosowane [6].

\section{Przyszłościowe substancje paliwowe oraz paliwa niestandardowe}

Omówione uprzednio substancje paliwowe mogą być wykorzystywane w całości lub w części, bezpośrednio, bądź po odpowiedniej przeróbce jako paliwa niestandardowe. Paliwa niestandardowe (nazywane potocznie i niepoprawnie paliwami alternatywnymi) spełniać mogą większość z wymagań określonej grupy urządzeń. Niemniej nie została ustanowiona na nie odpowiednia norma przedmiotowa wraz z określonymi normami na metody badań i w związku $\mathrm{z}$ tym paliwa te nie mogą być stosowane w silnikach i urządzeniach w okresie co najmniej gwarancyjnym, ponieważ nie są zalecane do stosowania przez producentów tych urządzeń. Niektórzy producenci wręcz zabraniają stosowania paliw niestandardowych w swoich urządzeniach.

Przyjmując za zasadne poszukiwanie nowych źródeł energii oraz prowadzenie prac nad poszukiwaniem korzystniej pracujących źródeł napędu, ciepła i energii elektrycznej, aktualnie $\mathrm{z}$ różnych względów, najczęściej poza technicznych zaleca się wprowadzanie lub stosowanie paliw niestandardowych jako komponentów paliw standardowych. Według [7] paliwa niestandardowe są to takie paliwa które spełniają następujące warunki:

- występują w dostatecznie dużych ilościach;

- cechują się technicznymi i energetycznymi właściwościami determinującymi ich przydatność do zasilania silników lub urządzeń grzewczych;

- są tanie w produkcji i sprzedaży;

- stanowią mniejsze zagrożenia dla środowiska niż paliwa dotychczas stosowane;

- zapewniają możliwe do przyjęcia wskaźniki ekonomiczne silników lub kotłów i bezpieczeństwo ich użytkowania.

Oprócz tego paliwa niestandardowe powinny:

- zapewnić niezależność energetyczną;

- mieć mniejszą emisyjność związków toksycznych w procesie ich spalania;

- umożliwiać niższe koszty eksploatacji silników i urządzeń grzewczych. Aktualne rozważane, zalecane do stosowania lub nawet stosowane paliwa niestandardowe, w chwili obecnej nie spełniają powyższych warunków.

Omówienie wszystkich możliwych substancji paliwowych oraz paliw niestandardowych znacznie przekracza ramy niniejszego opracowania. Podstawowe substancje paliwowe i paliwa niestandardowe stanowić mogą:

- gaz ziemny w postaci sprężonej CNG (Compressed Natural Gaz) i ciekłej LNG (Liquid Natural Gaz), zawierający głównie metan;

- gaz miejski, wytwarzany w procesie suchej destylacji węgla, zawierający metan, tlenek i ditlenek węgla; 
- wodór jako podstawowe paliwo do ogniw paliwowych lub składnik mieszanek ubogich;

- $\quad$ amoniak (azan) w postaci gazowej lub ciekłej otrzymywany na skalę przemysłową w procesie syntezy wodoru i azotu atmosferycznego;

- propan lub jego mieszanina z butanem jako mieszanina tak zwanego gazu naftowego i gazu ziemnego powszechnie wykorzystywany jako źródło napędu;

- alkohol metylowy i etylowy;

- eter dimetylowy DME i dietylowy DEE oraz etery wyższe, głównie: eter metylo-tert-butylowy MTBE, a także eter etylo-tert-butylowy ETBE, otrzymywane $\mathrm{z}$ syntezy tlenku węgla $\mathrm{i}$ wodoru oraz z gazu ziemnego, węgla, drewna i organicznych substancji odpadowych. Badana jest także przydatność eterów metylo-tert-amylowych TAME i diizopropylowych DIPE;

- oleje roślinne;

- estry metylowe FAME i etylowe FAEE wyższych kwasów tłuszczowych;

- oleje popirolityczne;

- gazowe i ciekłe produkty procesów termicznego i termokatalitycznego rozkładu organicznych substancii odpadowych, tłuszczów pochodzenia roślinnego i zwierzęcego w tym procesów termicznego rozkładu gum (opon) prowadzących do uzyskiwania ciekłych i gazowych produktów rozkładu, procesów depolimeryzacji tworzyw sztucznych, procesów prowadzących do uzyskiwania gazów składowiskowych (biogazów), gazów pirolitycznych pochodzących z rozkładu termicznego substancji organicznych, gazów syntezowych [8] i pochodnych substancji ciekłych typu SYNONBION jako paliwa niestandardowego mogącego zastąpić oleje napędowe.

Proces depolimeryzacji tworzyw sztucznych, prowadzący do otrzymywania niestandardowych komponentów, korzystny z punktu widzenia konieczności racjonalnego wykorzystania znacznych objętości substancji odpadowych niesie jednak cały szereg zagrożeń.

Tworzywa sztuczne, z racji ich znacznej odporności na biodegradację i niską świadomość ekologiczną społeczeństwa uznawane są powszechnie jako znacznie zagrażające środowisku. Trzeba jednak stwierdzić, że tworzywa te, właśnie z racji odporności na biodegradację nie wnoszą do środowiska substancji toksycznych i są odporne na działanie czynników atmosferycznych jak również wielu innych substancji chemicznych. Możliwy ich rozkład w środowisku w długotrwałych, trwających nawet do setek lat, procesach fotochemicznych i biologicznych. Skracanie okresu rozkładu polimerów jest możliwe w procesach chemicznych, po wprowadzeniu dodatków uwrażliwiających polimery na działanie substancji zwartych w glebie i wodzie. Proces biodegradacji polimerów zachodzi głównie poprzez działanie enzymów zawartych na powierzchni błon komórkowych niektórych szczepów bakterii. Proces ten w efekcie, po bardzo długim czasie doprowadza do powstania naturalnych związków, takich jak woda, ditlenek węgla i metan.

A zatem przemysłowe procesy depolimeryzacji odpadowych tworzyw sztucznych i wykorzystywanie produktów tej depolimeryzacji wnoszą znaczne zagroże- 
nia dla środowiska poprzez uwalnianie gazowych substancji procesowych, możliwość powstawania odpadów popirolitycznych, a także poprzez efekty spalania ciekłych produktów procesu jako komponentów paliwowych.

Taniość wytwarzania tworzyw sztucznych i nagminność ich stosowania stwarza jedynie możliwość pozyskania dodatkowych źródel energii oraz poprzez ich wtórne wykorzystanie do celów energetycznych jedynie znacznie poprawia walory estetyczne środowiska, eliminując zaśmiecanie i ograniczając konieczność ich składowania.

Dlatego też wszelkie próby wykorzystania zużytych substancji, głównie polietylenowych i polipropylenowych, zasługują na poparcie, pod warunkiem racjonalnego sposobu prowadzenia procesu i wykorzystania produktów po procesowych. Stąd też istotna jest jednoznaczność definicji i pojęć z tego zakresu.

Polietylen (poprawnie: polieten), o wzorze $\left(-\mathrm{CH}_{2}-\mathrm{CH}_{2}-\right)_{n}$ stanowi produkt polimeryzacji etenu, $\mathrm{H}_{2} \mathrm{C}=\mathrm{CH}_{2}$, najprostszego alkenu, stanowiącego pierwszy z nienasyconych węglowodorów z tej rodziny, zwyczajowo nazywanej olefinami. Nazwa ta pochodzi od łacińskiego „oleum affinis”, co oznacza, ze pochodne bromowe lub jodowe tych związków są "podobne olejom”, mając stosowną konsystencję i lepkość. Stąd też określona w normach przedmiotowych liczba bromowa lub liczba jodowa jest miarą stopnia nienasycenia olefin, czyli liczby wiązań podwójnych pomiędzy węglami w łańcuchu. Podobnie polipropylen stanowi produkt polimeryzacji propenu, $\left(\mathrm{CH}_{3}-\mathrm{CH}=\mathrm{CH}_{2}\right)$, drugiego w szeregu homologicznym olefin, w którego polimerach występuje zjawisko stereoizomerii wynikającego z obecności w łańcuchu asymetrycznego atomu węgla.

W prowadzonych procesach depolimeryzacji tworzyw sztucznych nadużywany lub jest używany niezbyt precyzyjnie, termin „parafiny”, co może prowadzić do nieporozumień związanych $\mathrm{z}$ istotą realizowanych procesów.

Nazwą zwyczajową "parafiny" objęte są węglowodory alifatyczne, nasycone, poprawnie według IUPAC nazywane alkanami, poczynając od gazowego metanu, poprzez ciekłe od pentanu i stałe od oktadekanu, w warunkach normalnych. Nazwa ta pochodzi od łacińskiego „parum affinis” - „mało pokrewne, powinowate” charakteryzującego stosunkowo małą reaktywność chemiczną tych związków. W procesach rafineryjnych realizowane są procesy odparafinowania: chemiczne (rozpuszczalnikowe) lub fizyczne (wymrażania) w celu usunięcia głównie $z$ frakcji olejowych wysokokrzepnących parafin, to znaczy długołańcuchowych alkanów podwyższających temperaturę krzepnięcia produktów finalnych. Z pozostałości po odparafinowaniu (może to być gacz parafinowy) otrzymuje się parafinę surową, a po oczyszczeniu parafinę rafinowaną. Z węglowodorów parafinowych ciekłych, w tym alkanów nie krystalizujących, otrzymywany jest olej parafinowy do zastosowań farmaceutycznych w przemyśle spożywczym.

A zatem proces depolimeryzacji odpadowych tworzyw sztucznych w procesach destrukcji termokatalitycznej (krakingu termokatalitycznego), bez udziału wolnego wodoru, prowadzić może do powstania niestabilnej mieszaniny ciekłych węglowo- 
dorów zawierającej alkeny, alkany oraz mniejsze ilości cykloalkanów i cykloalkenów wraz z arenami (mieszaniny olefnowo-parafinowej z udziałem naftenów i około $8 \%$ $\mathrm{m} / \mathrm{m}$ aromatów). Ponieważ realizowane procesy rozkładu prowadzone są $\mathrm{w}$ temperaturach ponizej $600^{\circ} \mathrm{C}$, to nie stanowią one pirolizy, a jedynie kraking termiczny.

Ponieważ procesy rozkładu termicznego mieszanin węglowodorowych prowadzą do skracania łańcuchów węglowodorowych i zwiększenia stopnia nienasycenia węgli w tych łańcuchach, a proces pirolizy prowadzi do uzyskiwania mieszanin ciekłych węglowodorów nienasyconych (tzw. benzyna popirolityczna kierowana do uwodornienia) i gazowych olefin przeznaczonych do procesów polimeryzacji na tworzywa sztuczne, to depolimeryzacja, prowadzona bez udziału wodoru, jako proces odwrotny doprowadzić może do powstania nawet gazowych olefin, a odpowiednio prowadzona, mieszanin ciekłych, głównie alkenowo-alkanowych.

Mieszaniny te nie mogą bezpośrednio stanowić silnikowych komponentów paliwowych ponieważ charakteryzują się:

- małą odpornością na utlenianie, wynikającą z zawartości olefin, charakteryzowaną okresem indukcyjnym sięgającym $68 \mathrm{~min}$. i zawartością żywic około $30 \mathrm{mg} / 100 \mathrm{~cm}^{3}$;

- zawartością alkenów (olefin) ponad $40 \% \mathrm{~m} / \mathrm{m}$;

- niską liczbą oktanową, motorową, około 57.

Produkty po procesie rozkładu z tworzyw sztucznych, po procesie odaromatyzowania i uwodornienia mogą być stosowane w produkcji niskoaromatycznych rozpuszczalników do farb i lakierów, a także wykorzystywane w przemyśle kosmetycznym i tłuszczowym. Mogą także stanowić wsad do procesów rafineryjnych, stanowiąc wprawdzie nieznaczny ułamek objętości ropy, po procesie dehydratacji. Kierowanie produktów rozkładu tworzyw sztucznych do procesów rafineryjnych stanowi najbardziej bezpieczną dla środowiska i techniki motoryzacyjnej metodę ich zagospodarowywania.

Na rozwagę zasługuje także możliwość zagospodarowywania ciekłych mieszanin parafinowo-olefinowych powstających w wyniku rozkładu termokatalitycznego tworzyw sztucznych, prowadzącą do powstania tzw. „oleju krakingowego”, który może stanowić komponent cieczy opałowych (olejów opałowych) przeznaczonych do urządzeń grzewczych. Kompozycja tych cieczy może zawierać także odpadowe, ciekłe frakcje w tym po krakingowe $\mathrm{z}$ instalacji próżniowej i slopy jasne (oleje slopowe) jako rozcieńczalniki. Tak sporządzone kompozycje paliwowe do urządzeń grzewczych po uprzednim od aromatyzowaniu i odpowiednim blendowaniu lub najkorzystniej destylacji mogą spełniać wymagania eksploatacyjne tych urządzeń. Wadą tego typu cieczy może być stosunkowo krótki czas ich magazynowania, ze względu na zawartość węglowodorów nienasyconych.

Ze względów środowiskowych i ekonomicznych, zasadna była by budowa instalacji do przetwarzania tworzyw sztucznych na ciekłe mieszaniny węglowodorowe na terenach istniejących rafinerii nafty. Istniała by wówczas gwarancja wykorzystywania produktów rozkładu tylko jako komponentów wsadowych w procesie 
rafineryjnym, bez możliwości bezpośredniego, szkodliwego dla silników spalinowych i dla środowiska dodawania tych komponentów do paliw silnikowych w różnego typu blendowniach, czy też bazach paliwowych, a także korzystniejszy był by bilans energetyczny procesu depolimeryzacji. W rafineriach, $\mathrm{z}$ racji istoty realizowanych tam procesów, występować może nadmiar energii, który może być w pełni wykorzystywany w krakingu termokatalitycznym tworzyw sztucznych.

\title{
Bibliografia
}

[1] J. Merkisz, „Ekologiczne aspekty stosowania silników spalinowych”, Wyd. Politechniki Poznańskiej, Poznań 1994.

[2 ] H. Skolimowski, „W matni postępu”, Wyd. Politechniki Lubelskiej, Lublin 1992.

[3] K. Baczewski, K. Biernat, M. Machel, „Leksykon, Paliwa, Oleje, Smary w Eksploatacji Samochodów", WKiŁ, Warszawa, 1993.

[4] K. Biernat, „Materiały Pędne i Smary”, WAT, Warszawa 1983.

[5] J. Merkisz, „Wymagania stawiane paliwom silnikowym przez współczesne silniki spalinowe”, Mat. II Międzynarodowej Konferencji pt: „Rozwój technologii paliw w świetle Dyrektyw Europejskich i Narodowych Uregulowań Normatywnych", Warszawa 1999.

[6] K. Biernat, Z. Karasz, „Paliwa plynne i ich użytkowanie”, Wyd. SIMP, Warszawa 1997.

[7] Henk P.M.Sengers, R. Eric Olsen, Emmanuelle D. Faure-Birchem, „Performance Tests for Diesel Injector Fouling, Fuel Foaming, and Related Functional Benefits”, Mat. II Międzynarodowej Konferencji pt: „Rozwój technologii paliw w świetle Dyrektyw Europejskich i Narodowych Uregulowań Normatywnych” Warszawa 1999.

[8] J.M. Mackowski, "The EU Directives on Fuels Quality: a look beyond year 2000”, Mat. II Międzynarodowej Konferencji pt: „Rozwój technologii paliw w świetle Dyrektyw Europejskich i Narodowych Uregulowań Normatywnych", Warszawa 1999.

[9] J. Gronowicz, „Ochrona środowiska w transporcie lądowym” Wyd. ITE Radom 2004.

[10]L.J. SitnIK, „Ekopaliwa silnikowe”, Oficyna Wydawnicza Politechniki Wrocławskiej. Wroclaw 2004.

[11] K. BaczewskI, T. KaŁDoŃsKI, „Paliwa do silników o zapłonie samoczynnym” WKE, Warszawa 2004.

[12]A. Vogt, H. Kolodziej. W. SokoŁa, J. FaŁat. S. Strzelecki, „Koncepcja CPE na bazie produkcji estrów etylowych wyższych kwasów tłuszczowych z olejów roślinnych”, „Sozologia’ nr $1 / 2003$.

[13]K. Biernat, A. Łuksa, „Węglowodory i tłuszcze odpadowe jako ciecze opałowe”, „Sozologia” nr $1 / 2003$.

[14]L.Pyskıo, W. Parasiewicz, „Recykling zużytych opon”, Wyd IPG, Piastów 2001.

\section{The forecast of development of the liquid fuels}

\begin{abstract}
The article includes analysis of basic terms and definitions and following issues: the directions of modification and development of the drive in the wheel vehicles, the forecast of development of standard fuels for internal combustion engines, the improvement of demands towards oils and fuel liquids, prospective fuel substances and non-standard fuels.
\end{abstract}

